\title{
Textural Study of Sediments of Barrow Strait, District of Franklin*
}

PENELOPE J. HENDERSON

Johns Hopkins University, Baltimore, Maryland

Introduction

In the late summer of 1962, the Canadian Hydrographic Service conducted an oceanographic study of Barrow strait from the CSS BAFFIN. During the survey, 139 bottom sediment samples were collected. It is the purpose of this report to describe the texture of these sediments and relate it to the known oceanographic features in the area.

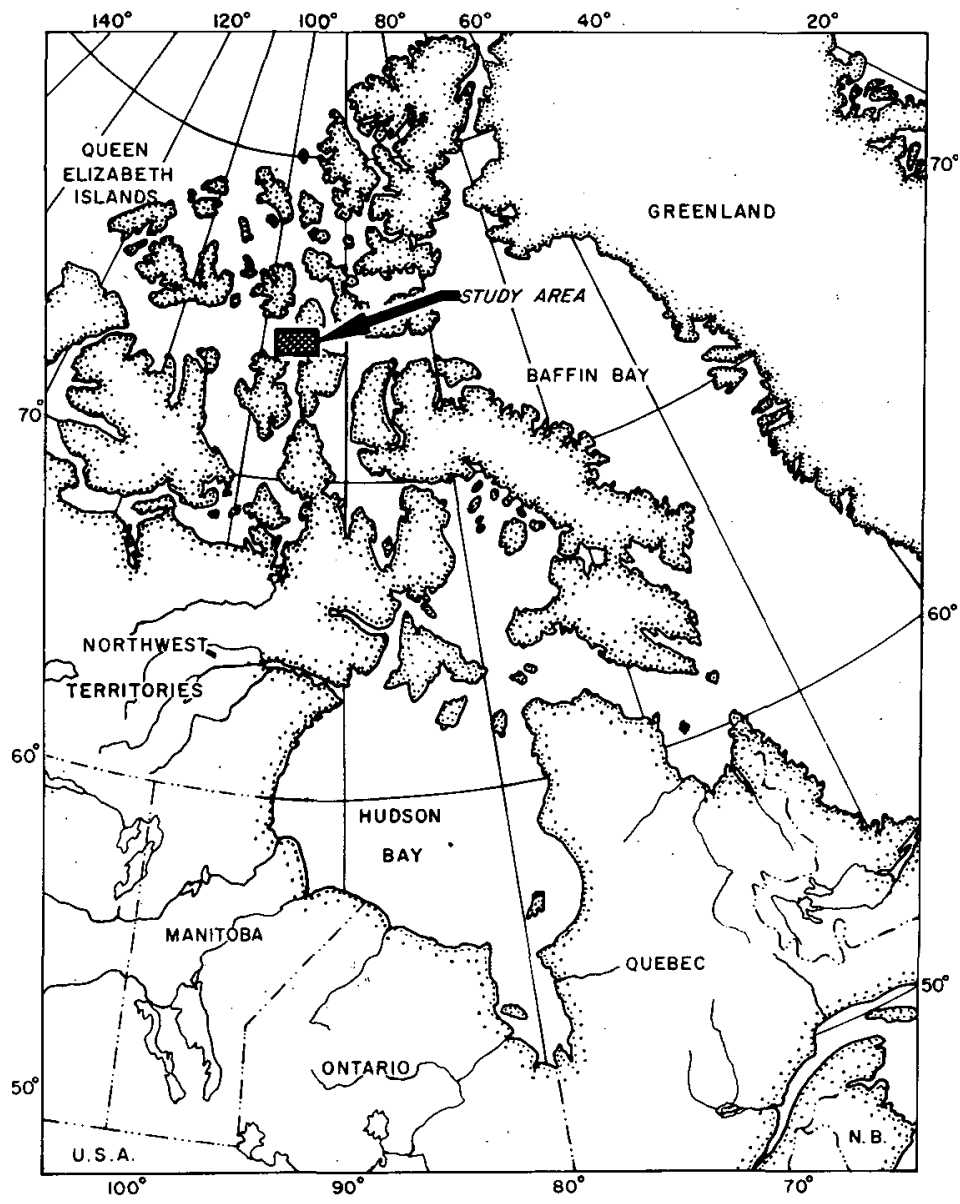

Figure 1 - Index Map of Area

Barrow Strait is located in the Canadian Arctic Archipelago (Fig. 1). It is approximately 165 miles long and varies in width from 30 to 60 miles. Together with Lancaster Sound, it forms the easternmost approach to the Northwest Passage joining the Arctic and Atlantic Oceans. The strait was discovered by Lieut. (later Admiral Sir) W.E. Parry in August 1819 during his search for the Northwest Passage (Parry, 1821) and was named by Parry after Sir John Barrow, Secretary of the Admiralty 1804-45.

Barrow Strait connects Lancaster Sound with Viscount Melville Sound. It is bounded on the south by Somerset and Prince of Wales Islands and on the north by Cornwallis and Bathurst Islands. Several large islands are situated in mid-channel. The largest of these include the following: Griffith Island, lying nine miles southwest of the south coast of Cornwallis Island; Russell Island, three miles off the northern coast of Prince of Wales Island; and Lowther Island, 22 miles north of the easternmost extremity of Russell Island.

Geologists have mapped some area of the Arctic Islands every year since 1947. Thorsteinsson (1958) examined the geology of Cornwalli's Island. Blackadar and Christie (1963) surveyed the areas of Somerset and Prince of Wales Islands. In 1955, the Geological Survey of Canada (Fortier et al, 1963) initiated an airborne study of the islands extending from Axel Heiberg and Ellesmere Islands on the north to Somerset on the south, and from Melville and Ellef Ringnes Islands on the west to Devon Island on the east.

* Manuscript received May 22; 1972. 
Detailed systematic study of the oceanographic features of the Arctic Islands is restricted to the past ten years. Previously, current and tidal information had been collected by the Canadian Hydrographic Service from observations made by ships passing through the area. Perry (1961) made a comprehensive study of the bottom sediments in the Canadian Eastern Arctic Archipelago. Several cores and bottom samples were taken from the extreme eastern portion of Barrow Strait. They consisted predominantly of very poorly"sorted light to olive grey to dusky yellow green material with a large percentage of pebbles and cobbles. Very little microfauna was present. Samples from Lancaster Sound obtained by the Canadian Hydrographic Service were studied by Buckley (MSc. Thesis, University of Western Ontario, 1962). Other work on Arctic Marine Geology is summarized by Pelletier (1966a) as well as an account on the development of submarine physiography in the Canadian Archipelago (Pelletier, 1966b).

\section{Regional Geology and Physiography}

In 1955 Fortier and Morley suggested, on the basis of geological and structural continuity, that the Arctic Islands were formerly a continuous landmass which is now partially submerged. Officers of the Geological Survey of Canada defined several geological regions in the Arctic Archipelago. The Barrow Strait sample area lies within the Cornwallis Fold Belt and the stable Melville Basin. Precambrian rocks of the Boothia Arch lie between Somerset and Prince of Wales Islands (see Figure 2).

The islands rise directly out of the strait to form plateaux ranging up to 800 and 1200 feet in elevation. These cliffs are composed of Ordovician and.Silurian dolomites, limestones and shales with some minor sandstone and siltstone. The regional northerly to northeasterly trending structures of Cornwallis Island are also present in structures on eastern Bathurst Island and Somerset Island. The north shore of Somerset Island is formed of limestone cliffs or steep slopes fronted by a zone of bars and lagoons. This low foreshore rises inland to a rolling plateau dissected by several large rivers which drain into Barrow strait.

The Paleozoic plateaux of Somerset and Prince of wales Islands are covered by a thin layer of glacial till. This area is believed to have been completely glaciated in the Laurentide ice sheet (Craig and Fyles, 1960). Although the distribution of glacial features within the area is meagre, large fragments of carbonate rock are present within the till. Precambrian boulders found on the islands are believed to have been carried by continental ice sheets. Jenness (1952) states that if the Arctic Islands north of Barrow strait and Viscount Melville Sound were glaciated it was the result of local ice accumulations. Cornwallis Island is covered with a mixture of clay and rock debris. The ice depositing this material is believed to have moved outward from a central location in the plateau (Fortier et a1, 1963).

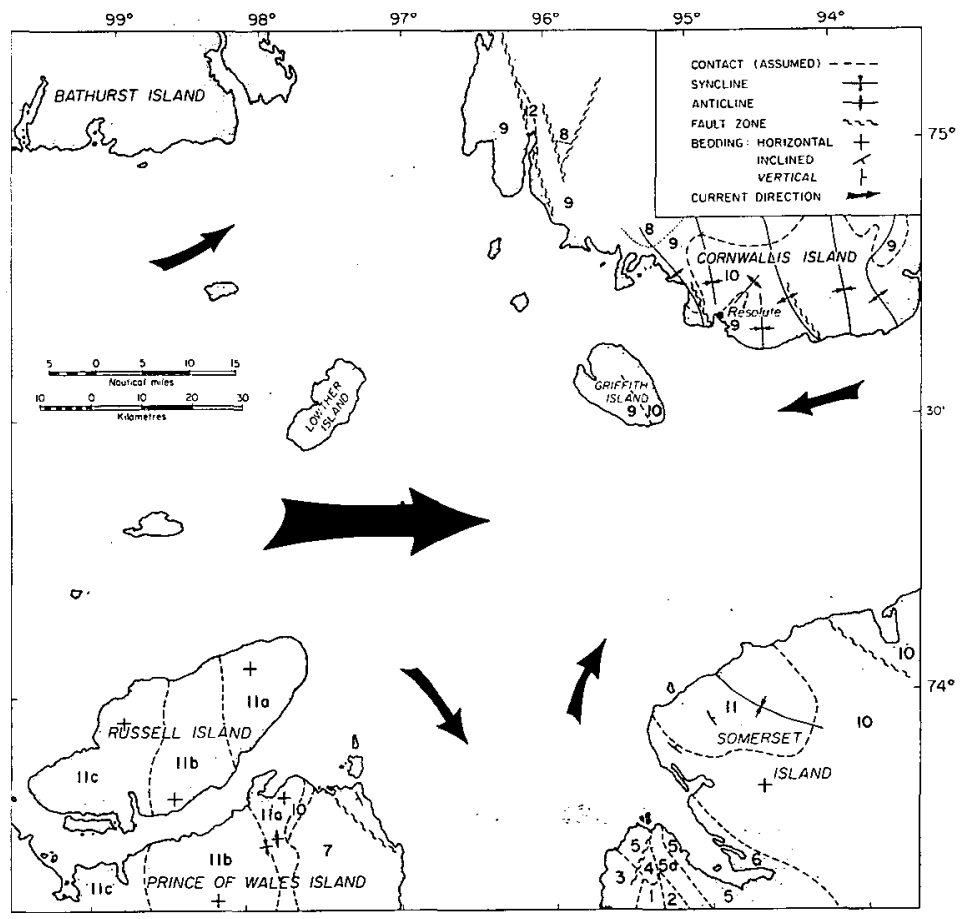

Figure 2 - Regional Geology and Currents (see Le gend on p. 128). 


\section{LEGEND (to accompany Fig. 2)}

12 PENNSYLVANIAN

Intrepid Bay Formation

Sand, Sandstone, Clay, Coal

11 SILURIAN AND (?) DEVONIAN

Peel Sound Formation

lla Boulder Conglomerate

lib Sandstone, sandy limestone, sandy shale

llc Mainly carbonate facies of Peel Sound Formation includes beds equivalent to Read Bay Formation and some beds younger than Peel Sound Formation.

10

SILURIAN

Read Bay Formation

Limestone, argillaceous limestone, calcareous shale, shale, dolomite, minor sandstone and siltstone.

9 ORDOVICIAN AND SILURIAN

Allen Bay Formation

Dolomite, minor limestone, dolomitic limestone, very minor amounts of argillaceous limestone and calcareous shale.

8 ORDOVICIAN

Cornwallis Formation

Limestone, argillaceous limestone, dolomitic limestone, dolomite

siltstone, shale, gypsum, gypsiferous shale, limestone breccia.

7 ORDOVICIAN AND (?) SILURIAN

Dolomite, dolomitic sandstone, mainly equivalent to Cornwallis and Allen Bay Formations.

6 Undifferentiated

MIDDLE CAMBRIAN AND (?) YOUNGER

Sandstone, sandy, dolomite, dolomite, shaly dolomite,

intraformational conglomerate.

5 PROTEROZOIC

Hunting Formation

Dolomite, sandy dolomite, minor shale, sandstone, chert,

5a Banded Dolomite

4

Aston Formation

Quartzite, minor shale, limestone, conglomerate.

3 ARCHEAN

Granite

2 Quartz-feldspar gneiss

1 Biotite-hornblende gneiss

see: Blackadar and Christie (1963, Fortier et al (1963) and

Thornsteinsson (1958).

Oceanography

Bottom Topography:

Barrow strait forms a sill averaging 175 metres in depth, and serves as a barrier preventing the free interchange of waters of the Arctic and Atlantic Oceans below 250 metres. This is reflected in the variations within the temperatures and salinities on either side of the strait (Hachey, Lauzier and Bailey, 1956).

The bottom of Barrow Strait is extremely hummocky and irregular (Fig. 3), although the floor slopes gently towards the east. Deep troughs are present in the channels separating the larger islands. In the passage between Bathurst and Cornwallis Islands a depth of 315 metres was recorded.

Water depth increases rapdily off the northeast coast of Somerset Island as well as Griffith and Lowther Islands. A profile across the strait from Cornwallis to Somerset Islands reveals the U-shaped configuration characteristic of glaciated river valleys. It has been postulated that the inter-island areas in the Arctic Archipelago developed initially as a Tertiary drainage system (Fortier and Morley, 1956) which has since been modified by glacial action (Pelletier, 1966). This is strongly evident within the strait as well as in Lancaster sound to the east. 


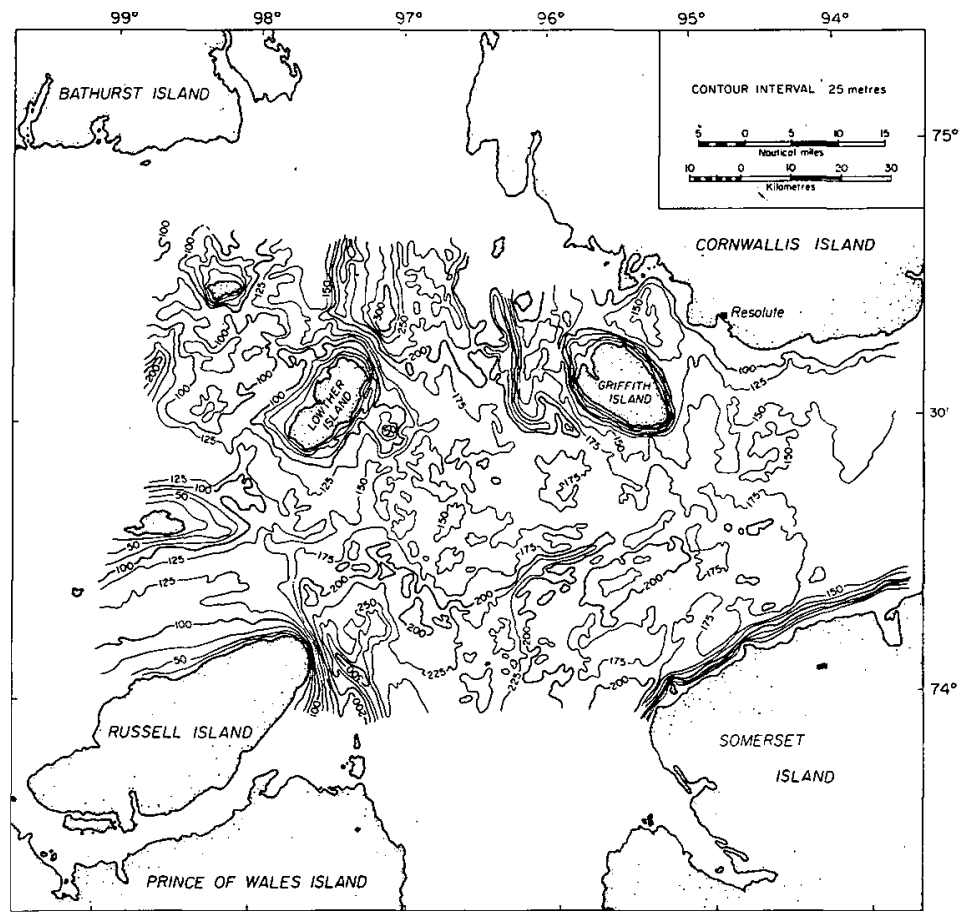

Figurz 3 - Bathymetry.

Although the northeastern coast of Russell Island drops steeply into the strait, the slope is less steep on the northern coast. Southerly trending currents entering Peel Sound, between Somerset and Prince of Wales Islands, likely account for the molding of the coastline and extensive erosion of the northeastern shore.

The geology of the islands indicates that the floor of Barrow strait is underlain by predominantly flat lying to slightly dipping Paleozoic rocks. The present topography is a result of the effects of ice and current action on this bedrock (Fig. 3).

\section{Tides and Currents:}

In the region of Lancaster Sound and Barrow Strait the maximum tidal range is six and onehalf feet. This decreases in the west to four feet (Pilot of Arctic Canada, 1963). The tides are semi-diurnal in character with two high waters and two low waters each day. There is, however, considerable variation in the heights of successive high and low waters. The ebb tide sets to the eastward; flood to the westward. Because of the general current flow from west to east through Barrow strait the ebb tidal stream has greater velocity.

The currents in the strait are the result of outflow of water from the Arctic Basin (Fig. 2). Surface currents are weak but flow predominantly eastward. There is a weak westward current on the north side of Barrow Strait. Currents enter Peel sound along the eastern coast of Prince of Wales Island and move into the strait along the western shore of Somerset Island (Collin and Dunbar, 1964). No information on currents between Bathurst and Cornwallis Islands was found although the bottom configuration suggests that they enter the strait through Griffith and Lowther Islands. Hachey, Lauzier, and Bailey (1956) report currents along the east coast of Cornwallis Island that move westward into Barrow strait.

\section{Ice Conditions:}

The general movement of ice in the Arctic region is eastward with the currents. In Barrow Strait, the winter ice remains unconsolidated and in constant tnotion due to the action of wind and tides. Schule and wittman (1958) report the formation of an expansion centre for the removal of sea ice south of Griffith Island in late March. From this central area the disintegration and removal of ice proceeds outward. The current packs the ice against the northern coast of Somerset, Russell and Prince of wales Islands. The ice in this area deteriorates in June and the whole passage is navigable from mid-June to mid or late september. Icebergs rarely drift as far as the east coast of Cornwallis Island. A considerable amount of ice may remain through summer even in the most favourable years but by early september the strait has less than $5 / 20$ coverage. 


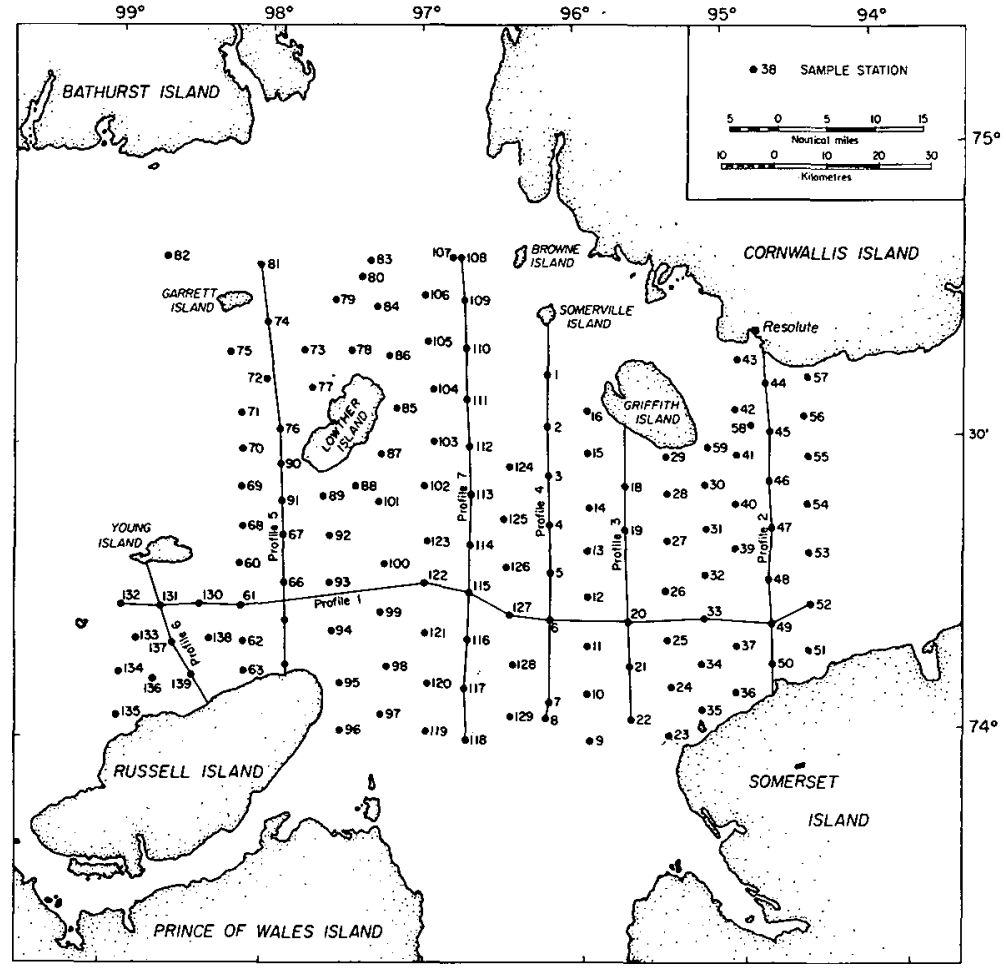

Figure 4 - Sample Stations and Profiles.

Bottom Sediments

Introduction:

The sampling of Barrow Strait was conducted by the Canadian Hydrographic Service in 1962. The sampling stations (Fig. 4) were positioned by means of two-range Decca, and were selected at 5-mile intervals along north-south lines which lay approximately five miles apart. These bottomsnapper samples represent the top 5 to $10 \mathrm{~cm}$ of sediment on the floor of Barrow Strait.

\section{Size Analysis:}

The size analyses were performed in the sedimentation laboratory at the Bedford Institute under the supervision of Mr. R. Cormier and Mr. T. Holler. The samples were separated into two size fractions by means of wet sieving through the 62 micron screen. The coarser fraction was dried and distributed by sieving into the wentworth size classes (Wentworth, 1922). Fine material was analysed by the pipette method (Twenhofel and Tyler, 1941). The size distribution was computed by calculating the weight of each size fraction as a percentage of the total sample weight of material less than $2 \mathrm{~mm}$ diameter. This data was plotted on a cumulative frequency curve with a logarithmic base. Because of the relatively small size of the sample, particles larger than $2 \mathrm{~mm}$ were excluded from the main computation. Although the gravel, sand, silt and clay fractions may initially have been deposited by the same agent, it is believed that the finer material would move in response to the currents acting within the strait while the gravel would tend to remain where deposited. As a result, the effect of bottom currents on the sediment distribution can only be determined by a study of the sand, silt and clay fractions. Observations of ice laden with sediment have been made in Arctic waters. Because Barrow strait is covered with ice a major part of the year and serves as a centre for ice break-up in the spring, it is suggested that this ice acts as the main source of sediment transport in the area.

\section{Gravel:}

The gravel fraction ( $>2 \mathrm{~mm}$ diameter) was calculated as a percentage of the total sample weight. This percentage is only approximate due to the extremely small size of the sample and the limitations of the sampling equipment. At three stations $(97,105,134$ ) only gravel was recovered from the bottom. Because only one pebble was recovered in each sample it is reasonable to assume that the pebble was caught in the jaws of the sampler thus permitting the winnowing of finer material, rather than assume that the bottom is covered by one hundred percent of gravel in that location. 
The percentage by weight of gravel in each sample has been plotted on Figure 5 . Although most stations contain a high proportion of the coarse sediment, such material appears in greatest concentrations along the noxth shore of Somerset Island, northwest of Lowther Island, and in a tongue extending from Cornwallis Island.

The high gravel content may be. due to the continuous movement of sediment-laden ice through the strait. During break-up ice is piled along the north shore of somerset Island and this may account for the exceptionally high proportions of gravel in that area. Similarly, interference of the predominantly eastward current of the strait and the westward drift around the east coast of Cornwallis Island would cause ice build-up leading to an irregular area of high gravel percentage. The large percentage of coarse material along the western portion of the sampled area may be caused mainly by the removal or lack of deposition of the finer material. Strong wave and current action developed in Viscount Melville Sound would tend to winnow and transport the fine material.

The steepness of the coasts and their proximity to the site of deposition in the strait presents an ideal situation for landslides or solufluction to contribute to bottom sedimentation. Thorsteinsson (1958) reports evidence of a massive landslide at Cape Hotham in southeastern Cornwallis Island that likely occurred in the late eighteenth, or early nineteenth century.

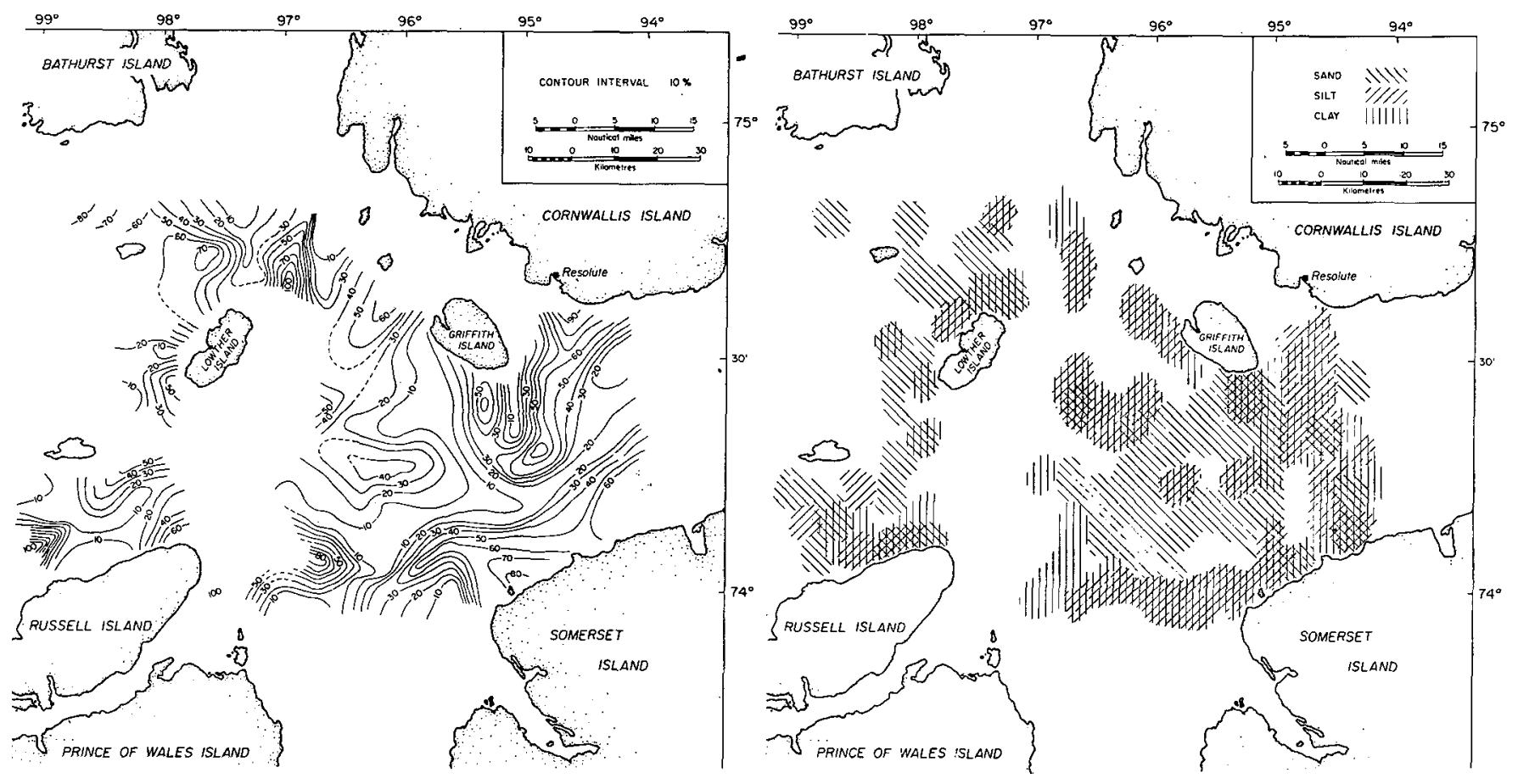

Figure 5 - Pз̀rcentage of Gravel.

Figure 6 - Modal Distribution.

\section{Sand, Silt and Clay:}

The results of the size analyses as plotted on the cumulative curve were accurate only to $0.001 \mathrm{~mm}$ diameter as the finer material was not separated into size classes. All size fractions less than $0.001 \mathrm{~mm}$ are grouped under the term colloid.

The sediments are too unsorted for any simple and meaningful classification. Frequency histograms of each sample showed a tendency for one or more size grades to make up the dominant part of the sediment. The most prominent grades constituted the mode of the sample. The grouped percentage of colloid particles tends to place a deceivingly high weight on the lowest size grade and any interpretation must be made with this in mind. Figure 6 illustrates the modal distribution of the samples within the strait (Grant, 1965). The coarser fractions are confined to the central and western part of the strait, where there appears to be little correlation between sediment size and water depth. 


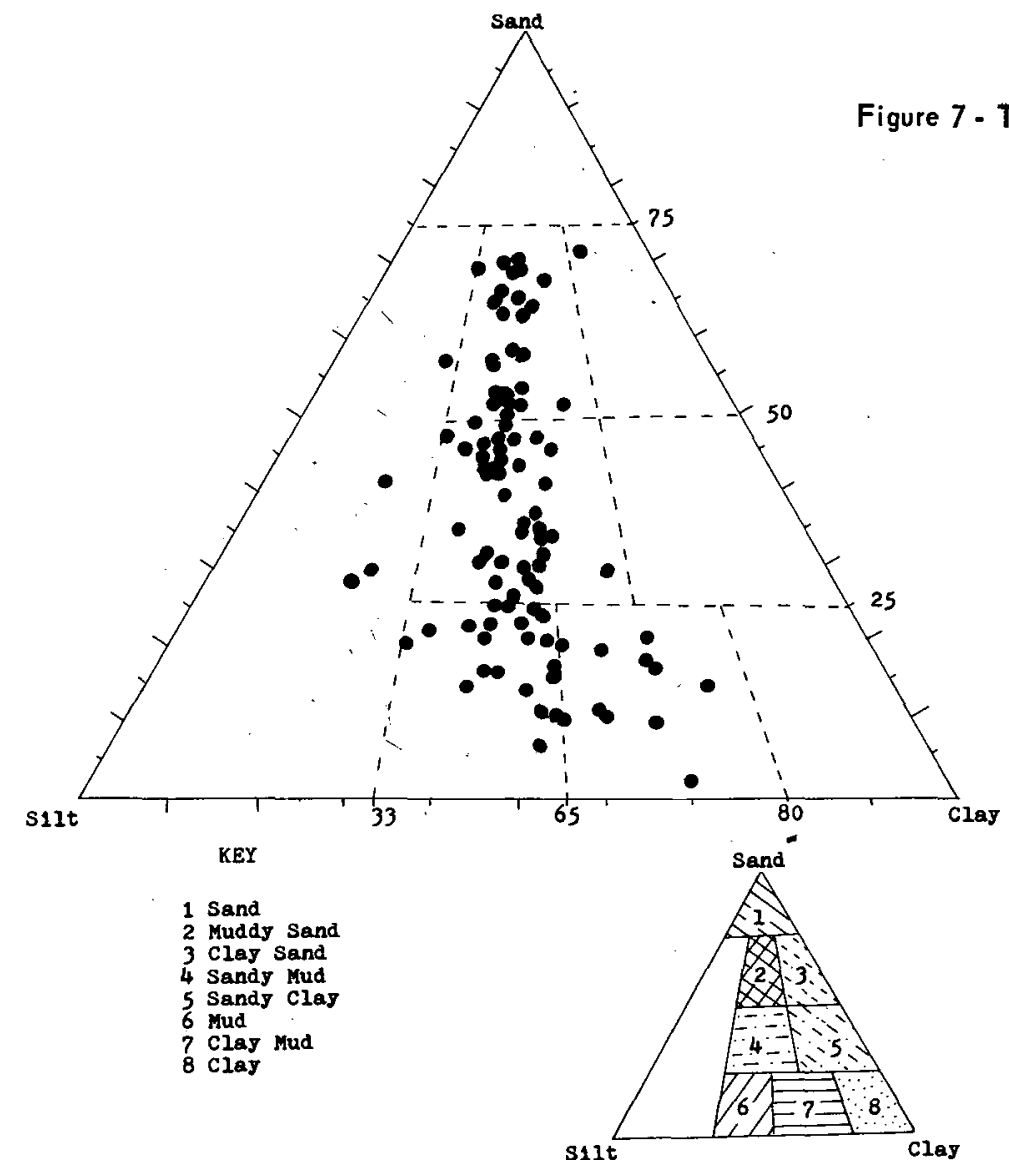

A more exact method of determining the sediment distribution was accomplished by plotting the relative percentages of sand, silt and clay on a ternary diagram (Fig. 7). The diagram was divided arbitrarily. into nine areas (Marlowe, 1965) in order to display the slight differences in sediment composition and texture. The samples are predominantly mud, sandy mud and muddy sand. The coarsest material is confined to the central portion of the strait and the northwestern corner of the sampled area (Fig. 8). Finer material occurs shoreward. Mud is confined to the more protected areas between islands in the northern part of the strait and in irregular pockets between Somerset and Russell Islands. These occurrences generally conform to areas of deeper water.

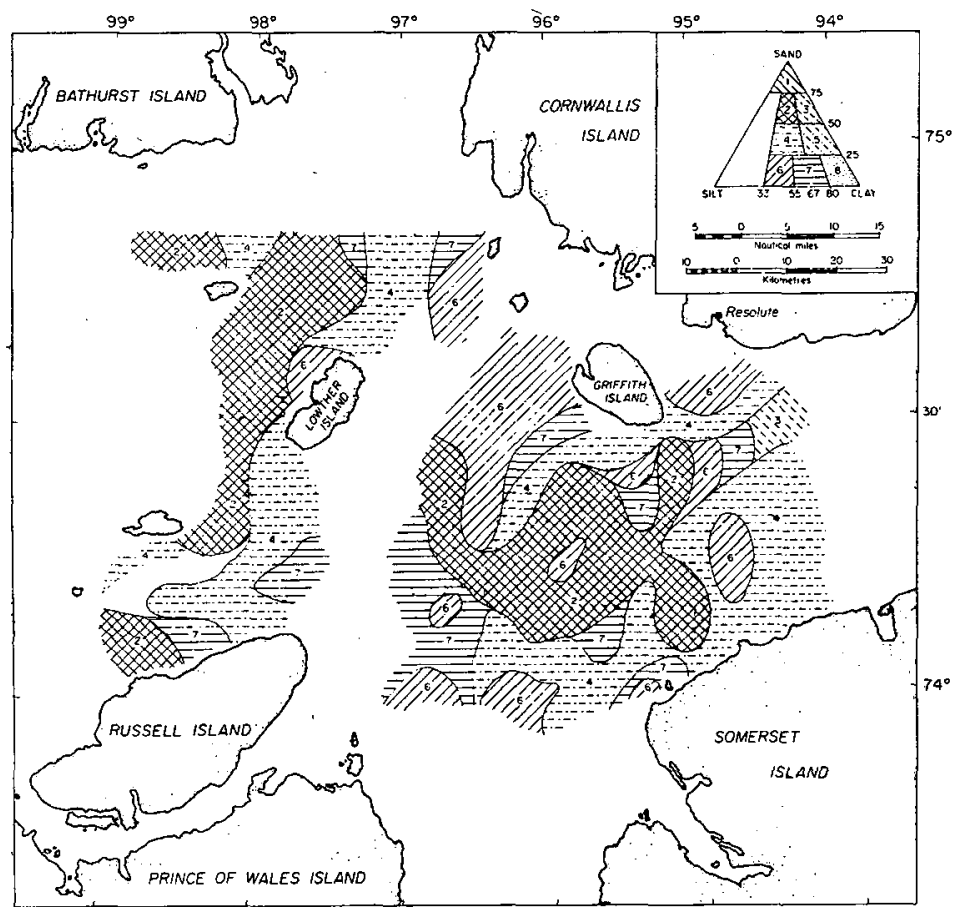

Figure 8 - S:diment, Distribution. 
South of Cornwallis Island, a zone of rapidly changing sediment texture is present. This intermixing of sediment types may be due to interference of the eastward current with the westward current which moves along the north shore of Lancaster Sound and Barrow Strait. Because of the shallowness of the strait, surface currents are more likely to represent bottom current velocities. This current velocity is more likely to affect the sediment than the bottom topography. Only areas behind islands are protected from strong current action and, therefore, fine material may accumulate.

Figure 9 shows the distribution of clay within the strait as a percentage by weight of the fraction less than $2 \mathrm{~mm}$. Those areas with-more than 30 percent clay material are indicated by diagonal lines. The clay content is higher in the deeper, eastern part of the strait. Areas south and west of Griffith Island and east and north of Russell Island also show high clay percentages (greater than 50 percent). Although these coincide with deeper water areas between Russell and Young Islands and in the northern strait, there generally appears to be little relationship. Compared with other studies of bottom sediment from Arctic areas (Marlowe, 1965 and Grant, 1965), the clay percentage in Barrow Strait is generally low. The relative percentage of clay within an area has been used as an indicator of current strength. It is reasoned that clay will only accumulate in areas of low current competency. From the distribution shown in Figure 9 , the strongest current moves eastward through the central part of the strait, where it winnows the clay and leaves the coarser material in the western portion of the sampled area. The current strength decreases through the strait, thus allowing the accumulation of clay in the eastern portion to take place.

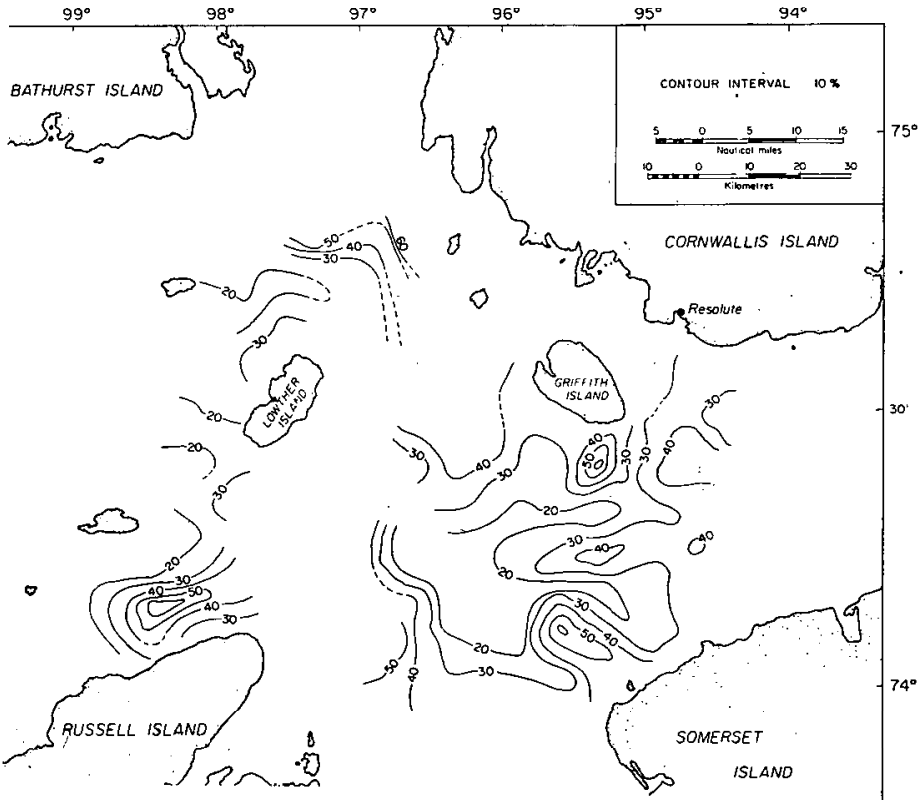

Figure 9 - Percentage of Clay.

\section{Statistical Measures:}

Because a large percentage of the Barrow strait samples contained more than twenty-five percent material in the colloid range, the cumulative curve had to be extrapolated to the seventyfive percentile. As a result, statistical analysis was limited to calculation of the median grain size and the coefficient of sorting based on quartile measures.

The median diameter is that diameter defined by the intersection of the cumulative curve with the fifty percentile (Krumbein and Pettijohn, 1938). The distribution of median diameters contoured at $0.02 \mathrm{~mm}$ intervals is illustrated in Figure 10. Because of the bimodal character of the sediment the average diameter is an ineffective method of describing. the sediment texture in this case.

Trask (1932) defines the sorting coefficient as the square root of the ratio of the first and third quartile grain diameters $\left(S_{0}=\sqrt{ } Q_{3} / Q_{1}\right)$. The first and third quartiles are defined as those diameters intersecting the cumulative curve at the twenty-five and seventy-five percentiles respectively. A sorting coefficient less than 2.5 is indicative of good sorting while one greater than 4.5 indicates poor sorting. 


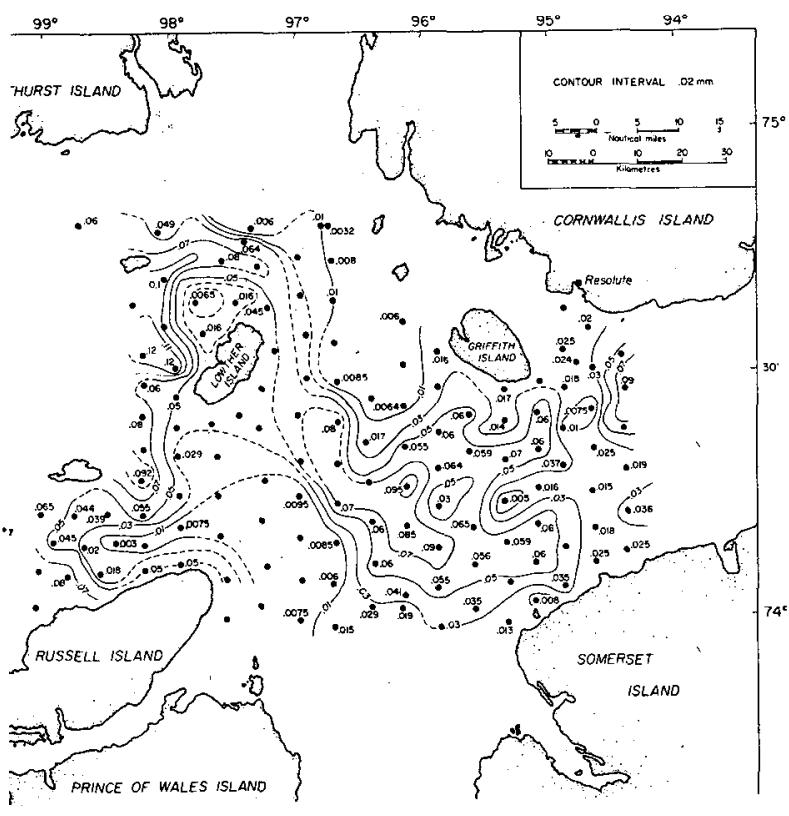

Figure 10 - Median Diameter.

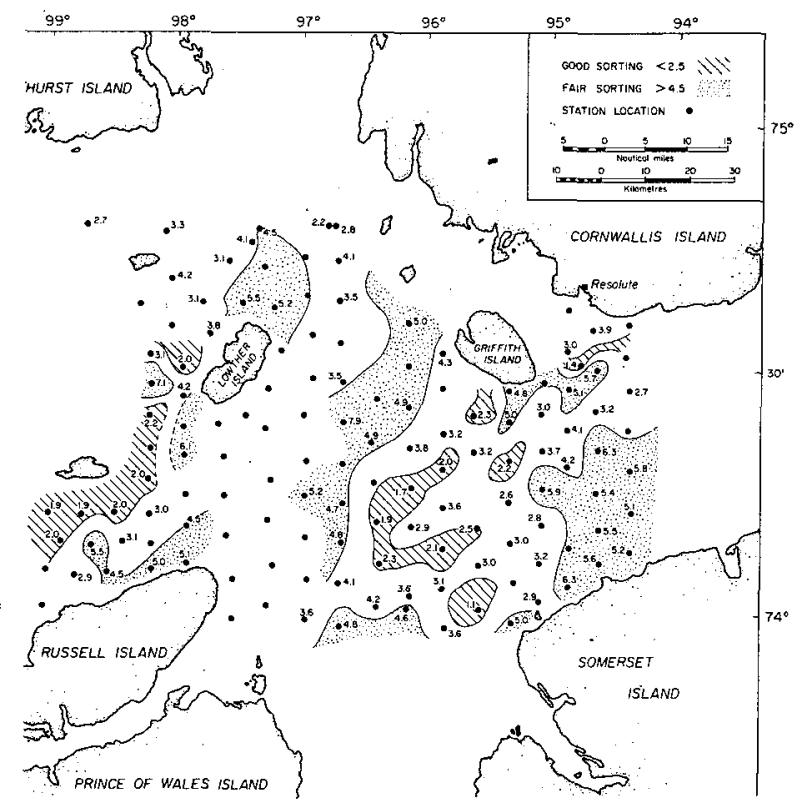

Figure 11 - Coefficient of Sorting.

The sorting of the sediment within Barrow strait is shown in Figure 11. Areas of good sorting have been crossed by diagonai lines. These areas appear to be coincident with the coarser, sandy material. Good sorting within these sand zones indicates that fine material is not accumulating either because strong currents have winnowed the fine particles out, or because these currents have prevented these fines from settling. Because of the long periods of ice cover and subsequent melting in the strait, it is likely that fine material from the ice was deposited over the whole area and redistributed by current action.

Good sorting in clay zones indicates lack of current action allowing for clay deposition and accumulation. This generally occurs within deeper water areas. Although larger size fractions may be deposited, they accumulate at a much slower rate and are masked by the clay material.

In the strait, sediments with a high clay percent are generally poorly sorted. Areas of poor sorting are shown in Figure 11. Although fine material does settle in fairly large proportions, other size fractions are well represented. This unsorted material is commonly found in glaciated areas. Although Barrow strait is not believed to have undergone continental glaciation (Craig and Fyles, 1960), it is covered by ice for a large part of the year. The presence of fine material indicates that current action has not been strong in these areas since the time of original deposition of the sediment from the ice.
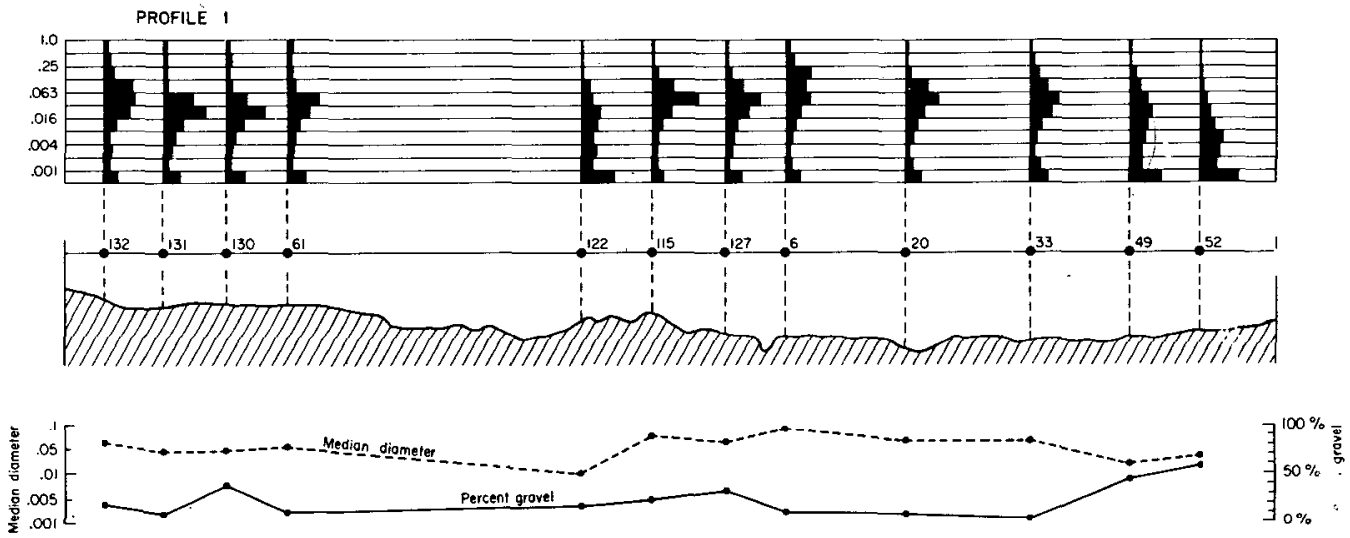

Figure 12 - Sedimentological and physiographic profiles across Barrow Strait. 
Figure 12 - continued
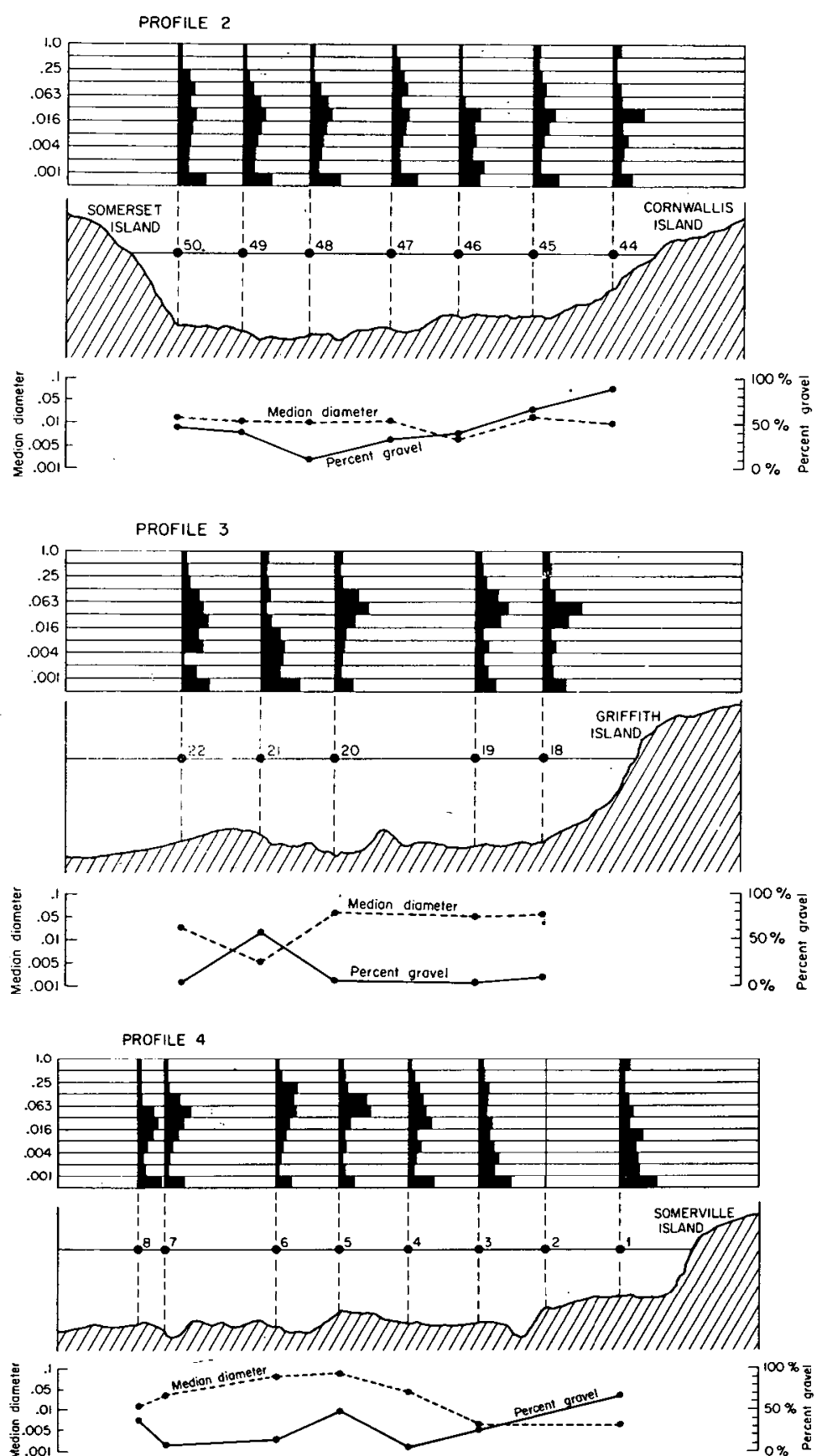

Figure 12 - continued
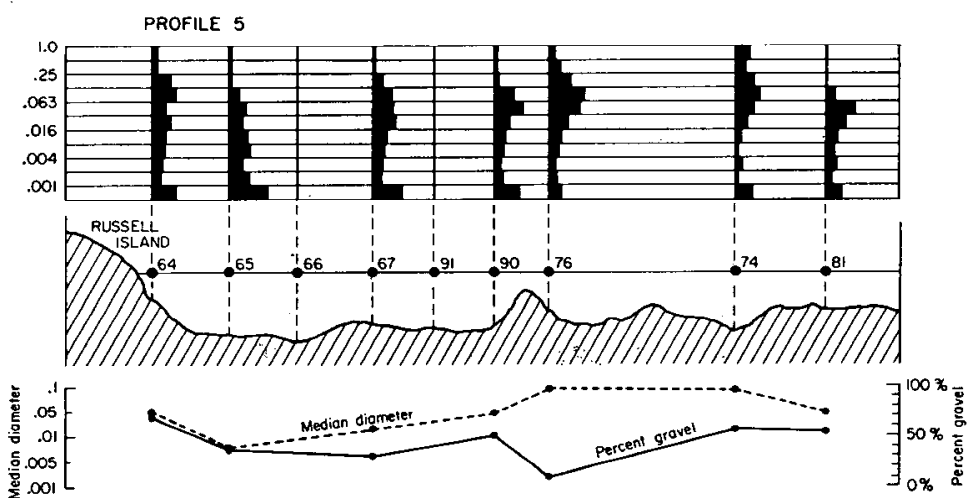

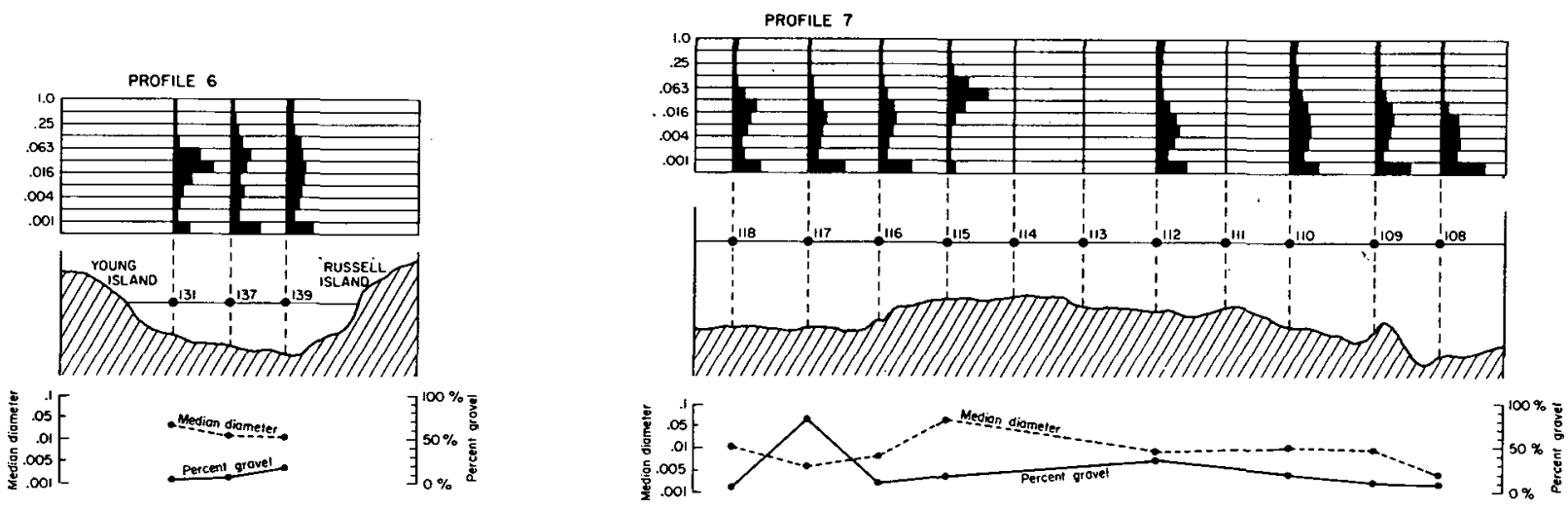

Figure 12 - continued

\section{Physiographic Profiles}

Physiographic profiles were drawn across Barrow strait (Fig. 12) in the locations illustrated in Pigure 4: For each station along the profile the size frequency histogram, median diameter and percent material greater than $2 \mathrm{~mm}$ diameter was plotted. There are indications that the textural features are controlled by the bottom topography to a very minor extent. In profiles 6 and 7 , the median diameter varies inversely with the depth. Similarly, the shallower western portion of the strait contains coarser material than the east (Profile 1). Profiles 2, 3, 4 and 5, however, lack any regular variation in grain size due to the bottom topography. In profiles 2 and 3 , there is relatively little change in grain size across the profile while in 4 and 5 , the sediment is coarser in the centre of the strait.

The gravel fraction of the sediment tends to be greater in shallow areas and in the centre of the strait where currents are most active. Accumulations are present around hummocks in the bottom topography.

Summary

The data available for study provided incomplete coverage of the sampled area in Barrow strait. Certain trends and patterns concerning the distribution of bottom sediments could be inferred, however. From these, the main factors controlling the distribution have been developed. Despite a similar source, size grades will react differently to the action of bottom currents. Gravel will tend to accumulate where deposited while smaller size grades may be transported. As a result, only material less than $2 \mathrm{~mm}$ diameter was used to determine the hydraulic conditions effecting sedimentation within the strait.

The sediment consists predominantly of poorly sorted silt and mud with pebbles greater than $2 \mathrm{~mm}$ in diameter comprising a large portion of the sample weight in some cases. The strait is covered with ice until mid-August and serves as a centre for the ice break-up in the spring. Because of these conditions and the nature of the sediment itself, it is believed that the bottom material is derived mainly from the ice. Some material may be added through river runoff, solufluction and mudflows from the surrounding islands.

In Barrow Strait the bottom material appears to be well agitated, which may be due to the existence of bottom currents. The distribution in the strait, therefore, appears to be controlled mainly by currents and, in part, by bottom topography. The coarsest material is on the western side of the strait, which is shallower than the eastern portion, and is subjected to the strong wave and current action from Viscount Melville Sound.

\section{References cited}

BLACKADAR, R.G. and CHRISTIE, P.L., 1963, Geological reconnaissance, Boothis Peninsula, and Somerset, King William and Prince of Wales Islands, District of Franklin. Geol. Surv. Can., Paper 63-19. 
COLIIN, A.E., 1962, The waters of the Canadian Archipelago. Report B.I.0. 62-2. and DUNBAR, M.J., 1964, Physical oceanography in Arctic Canada. Oceanogr. Mar. Biol. Ann. Rev., vol. 2, pp. 45-75.

CRAIG, B.G. and FYLES, J.G., 1960, Pleistocene geology of Arctic Canada. Geol. Surv. Can., Paper 60-10.

FORTIER, Y.O. and MORLEY, L.W., 1956, Geological unity of the Arctic Islands, in ocean floors around Canada. Trans. Roy. Soc. Can., vol. 1, series 3, pp. 3-12.

et a1, 1963, Geology of the north-central part of the Arctic Archipelago, Northwest Territories (Operation Franklin). Geol. Surv. Can., Mem. 320.

GRANT, A.C., 1965, Distributional trends of the Recent marine sediments of northern Baffin Bay. Report B.I.0. 65-9.

HACHEY, H.B., LAUZIER, L., and BAILEY, W.B., 1956, Oceanographic features of submarine topography, in ocean floors around Canada. Trans. Roy. Soc. Can., vol. 1, series 3, pp. 67-81.

JENNESS, J.L., 1952, Problems of glaciation in the Western Islands of Arctic Canada. Bull. Geol. Soc. Am., vol. 63, pp. 929-952.

KRUMBEIN, W.C. and PETTIJOHN, F.J., 1938, Manual of sedimentary petrology. D. Appleton-Century Co., Inc., N.Y., London.

MARLOWE, J.I., 1965, Sedimentology of the Prince Gustaf Adolf Sea area, District of Franklin. Report B.I.O. 65-15.

PARRY, W.E., 1921, Journal of voyage for the discovery of a northwest passage from the Atlantic to the Pacific performed in the years 1819-20 in HMS Fury and Hecla, 2nd edition, John Murray, London.

PELLETIER, B.R., 1964, Development of submarine physiography in the Canadian Arctic and its relation to crustal movements. Report B:I.O. 64-16.

PERRY, R.B., 1961, A study of the marine sediments of the Canadian Arctic Archipelago. Fish. Res. Bd. Can., Manuscript Report No. 89.

PILOT OF ARCTIC CANADA; Canadian Hydrographic Service, Surveys and Mapping Branch, Department of Mines and Technical surveys, Ottawa, vol. I, 1959; vol. II, 1959, pp. 233-266; vol. III, 1961, pp. 223-252.

SCHULE, J.J., Jr. and WITTMAN, W.I., 1958, Comparative ice conditions in North American Arctic, 1953-1955, inclusive. Trans. Amer. Geophy. Un., vol. 39, no. 3, pp. 409-19.

SUTHERLAND, P.C., 1852, Journal of a voyage in Baffin's Bay and Barrow strait in the years 185051, performed by HMS Lady Franklin and Sophia under the command of William Penny, vols. 12, Longman, Brown, Green, and Longman, London.

THORSTEINSSON, R., 1958, Cornwallis and Little Cornwallis Islands, District of Franklin, Northwest Territories. Geol. Surv. Can., Mem. 294

THORSTEINSSON, R. and TOZER, E.F., 1960, Summary account of structural history of the Canadian Arctic Archipelago since Precambrian time. Geol. Surv. Can., Paper 60-7.

TRASK, P.D., 1932, The sediments in the "Marion" expedition to Davis Strait and Baffin Bay, Scientific Results, Part I. U.S. Treasury Dept., Coast Guard, Bull. 19, pp. 62-81.

TWENHOFEL, W.H. and TYLER, S.A., 1941, Methods of study of sediments, New York, McGraw-Hill, 183 pp.

WENTWORTH, C.K., 1922, A scale of grade and class terms for clastic sediments. Jour. Geol., vol. 30, pp. 377-392.

NOTE: Appendices are on file in Report B.I.0. 67-6. 